\title{
Application of Eco Tropical Themes and Concepts in Rehabilitation and Beach Security Training Centers in Buleleng, Bali
}

\author{
Made Ngurah Viko Kurniawan ${ }^{1}$, I Gusti Ngurah Anom Rajendra², I Ketut Muliawan Salain ${ }^{3}$ \\ Bachelor Degree of Architecture Study Program \\ Faculty of Engineering-Udayana University \\ Jimbaran \\ madeviko@gmail.com \\ Architecture Study Program \\ Faculty of Engineering-Udayana University \\ Jimbaran \\ Architecture Study Program \\ Faculty of Engineering-Udayana University \\ Jimbaran
}

\begin{abstract}
The Rehabilitation and Coast Security Training Center is a place that designed to accommodate training activities from Coastal Rehabilitation and Coastal Management. The Coast Security Rehabilitation and Training Center is an organi-zation under the Regional Disaster Management Agency, in this planning the building will be designed in the Buleleng area due to several supporting factors, namely, in the province of Bali the Buleleng area has the longest coastline area others in Bali there are 172,301 Km (BPS Buleleng 2015). So that it needs a forum to train people to protect the coast and preserve the existing beaches, other factors that determine the Buleleng area, especially on Sawan Sangsit vil-lage, have similar organizations so expected the building designed will accommodate the activities of the existing or-ganization in the Buleleng area. In the process of designing the Beach Security and Rehabilitation Training Center, it starts from determining the theme by observing the condition of the surrounding area and adjusting it to local customs and culture so that the appearance of buildings can be in harmony with the appearance of the surrounding buildings and acceptable to the community.
\end{abstract}

Index Terms - training center, rehabilitation, coastal security, buleleng, bali.

\section{INTRODUCTION}

Eco Tropical Is a building design concept that is developed based on the climate of the environment where the building will be designed in addition to considering the climate of the eco tropical concept building also pay attention to the best possible use of energy in order to minimize energy waste in designing the building one example is maximizing openings in the building so that lighting and also air circulation in buildings can run smoothly.

At the Beach Rehabilitation and Security Training Center that is being planned will use the Eco Tropical concept where the planned building will be made with due regard to the climate at which the building will be built, where the planned building will be designed in the Buleleng area of Sawan sub-district, Sangsit village where the site location is located at beach

The choice of building planning in the area in Buleleng is because in Bali Province the longest coastline is located in the Buleleng regency with a coastline length of $172,301 \mathrm{Km}$ (BPS Buleleng 2015), but on the coast in Buleleng District from Tejakula Subdistrict it is reached in Gerokgak District. along 69.96 KM (BWS Bali-Penida 2018) the coast in North Bali was hit by abrasion. This beach damage is spread with varying degrees of damage from mild, moderate, and severe abrasion, besides that according to the head of the 
Bali Provincial Environment Agency, in Singaraja in Buleleng regency about $30 \%$ of the 3,000 hectares of coral reefs in the sea waters of the district of Buleleng, Bali , experiencing damage other than the swift water currents, other causes of damage are sedimentation, pollution, and disposal of plastic waste so that in addition to this building will accommodate activities to be able to overcome the existing problems the building will be designed environmentally friendly so that it does not cause negative impacts on the location of the building will be designed later.

In addition to paying attention to the environment of the building, planning will be made. Building the Rehabilitation and Beach Safety Training Center is designed in accordance with local culture so that the building can be integrated with existing buildings and can also be accepted by the surrounding community.

\section{RESUlt AND ANALISYS}

\section{A. Themes}

Eco Tropical Architecture is a representation of the concept of shape developed based on the response to climate experienced by tropical countries. the concept of tropical architecture, basically is the adaptation of buildings to tropical climates, where tropical conditions require special handling in its design. the main effect comes from conditions of high temperature and high humidity, where the effect is on the level of comfort when the user is in the room. other than that the design and planning stages will be based on nature and sustainability, where this is done to reduce excess energy use, in this case the Beach Rehabilitation and Security Training Center is designed using these themes by taking into account several factors such as building orientation, material use, building view , Building openings, and building construction that will be used later, in addition to a number of things, it is also necessary to pay attention to several approaches such as the Function Approach as a means of accommodating activities, the Social Approach so that the building can be accepted by the surrounding community, the Climate Approach pays attention to the condition of the climate where the building will later will be designed, and the Location Approach pays attention to where the location of the building will be designed. The following is a picture of one of the concepts of the application of the Tropical Tropical in Buildings where air flow is made in such a way that hot air is available on da building can flow out of the building [1] can be seen in figure 1 .

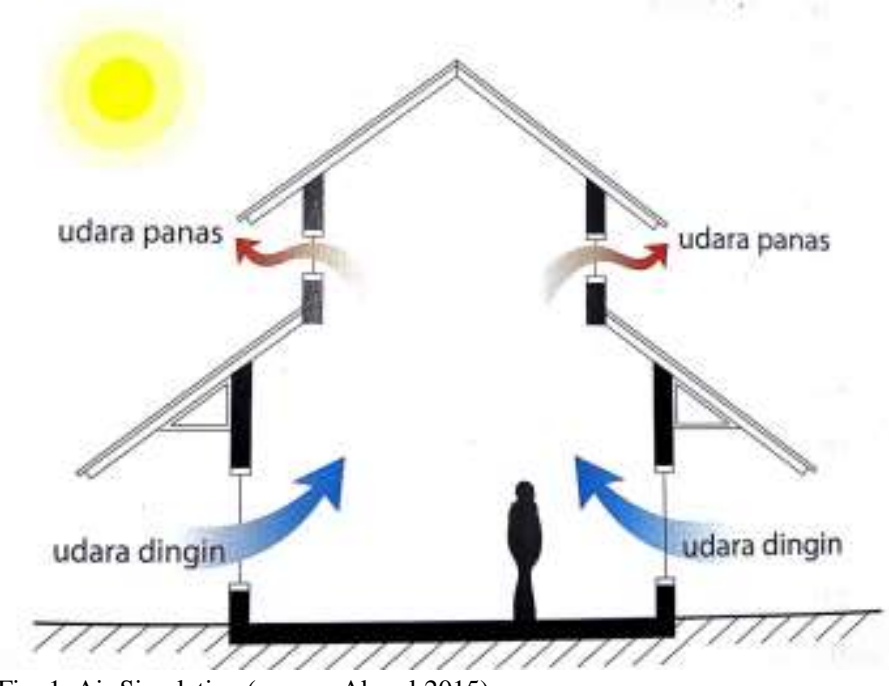

Fig. 1. Air Sirculation (source: Akmal:2015)

In Figure 1 is an example of the application of the Eco Tropical concept in buildings where cool air coming from outside the room is made to enter through the lower window and the hot air inside the building is channeled through a vent at the top of the building so the room will feel cooler

\section{B. Concept}

In the application of the concept of Eco Tropical in the arrangement of buildings arranged with the concept of centralized arrangement and in the center is the field as an open area and also the orientation of the view of the building will lead to the beach and also in the openings of the building preferably located in the east and north so that the air in the building can run smoothly and also lighting in buildings is obtained with maximum as for these things can be seen in Figure 2.

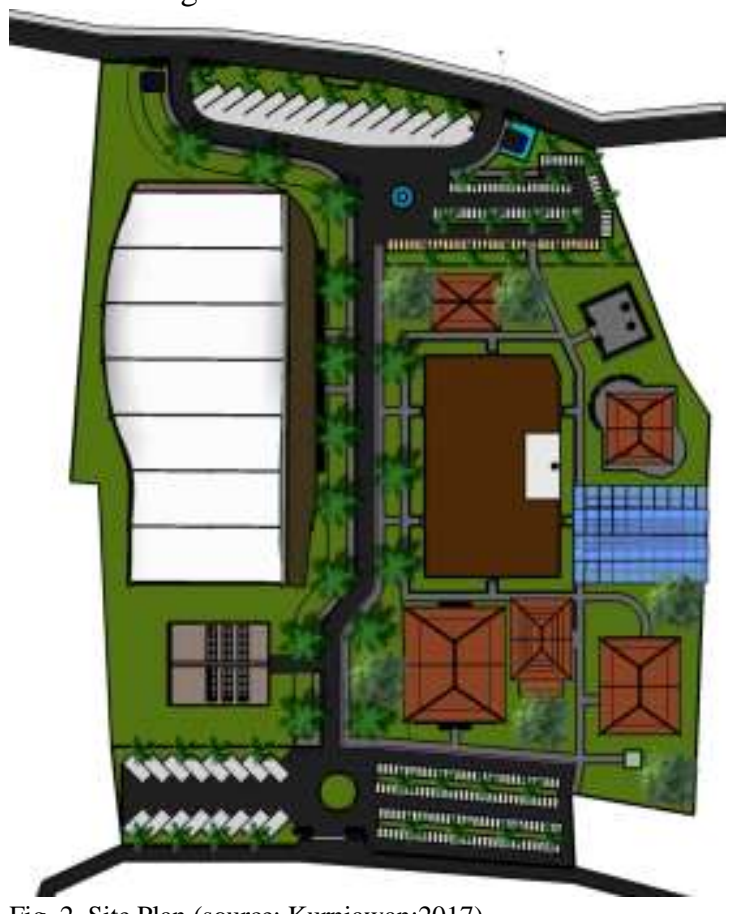

Fig. 2. Site Plan (source: Kurniawan:2017) 


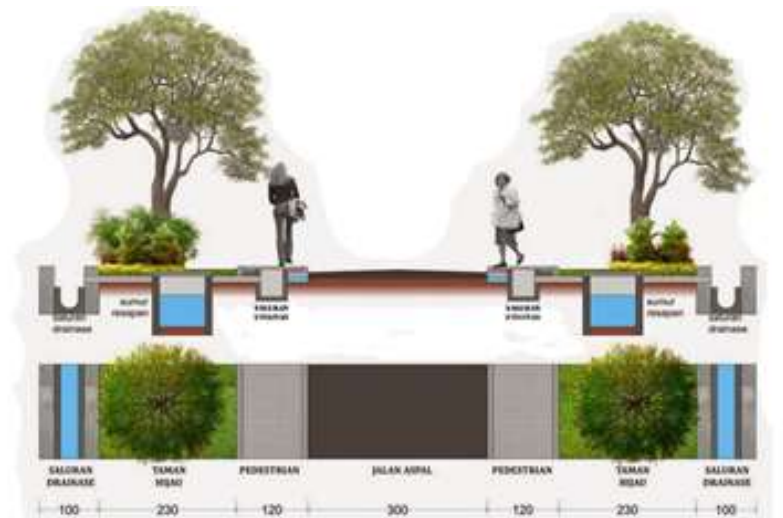

the planned outdoor space pays attention to how the pedestrian system and also the good drainage, so that with good drainage both activities and plants will be maintained

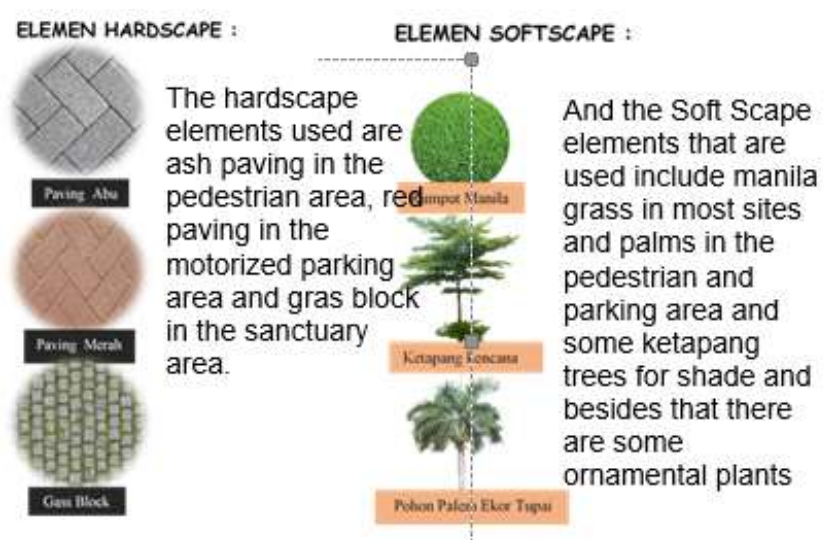

Fig. 3. Landscape (source: Kurniawan:2017)

In the picture above shows on the planning site the Beach Rehabilitation and Safety Training Center uses a centralized concept where all buildings focus on open fields and fields as the focal point of the planned building and also in building planning maximizing open areas so that the absorption of rain water is not disturbed so that plants can still live well and not damage the environment, other than that by paying attention to the climate in the area where the building will be designed the building openings are planned well, and also in plants that are used are plants that can live in the building area will be designed.

\section{Building Concept}

In the application of the building taken from the building used as a swimming pool where buildings with swimming pools using the concept of Eco Tropical are applied to the roof of the building where the roof of the building has openings so that air will be able to freely enter and exit the pool area so that the condition of the room is not too hot apart The application of the Eco Tropical theme is also located on the building body area by maximizing the use of glass so that the lighting in the room will be very maximum so that it can save energy used, as for the appearance and perspective can be seen in Figure 3.

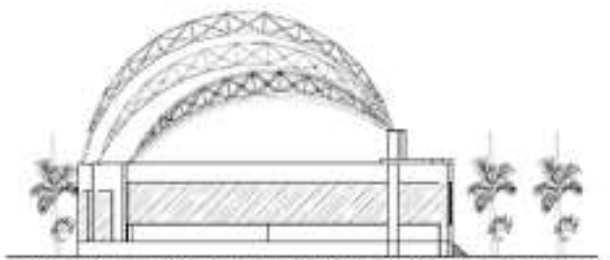

On the roof of the building is made open so that air circulation in the building will run smoothly and in the training pool room will feel cool.

The lighting in buildings is maximized by using glass so that natural lighting can enter the building well, and the Eco Eco Tropical concept that is energy efficient can be applied to design.
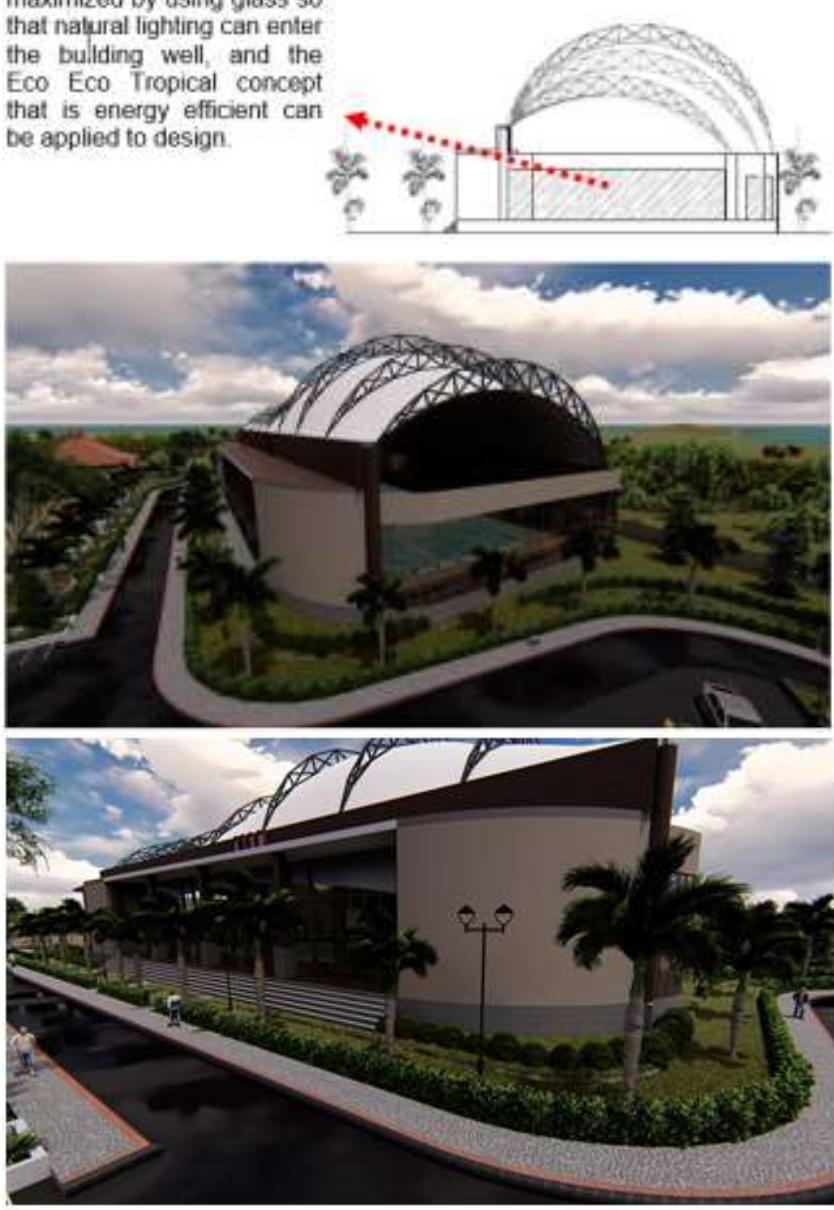

Fig. 4. Building Concept (source: Kurniawan:2017)

In Figure 4 in addition to using the exercise pool, the Eco Tropical concept also takes into account the use of materials that are appropriate to the local area, where in the Buleleng area, especially Sawan sub-district, Sangsit village, where the building is planned to use a lot of material in the form of rocks, white sand, teak wood material and coconut wood where coughs and white parasites are placed on the walls of the building as ornament sticks and teak and coconut wood are used in the interior and to decorate the building exterior

\section{CONCLUSION}

Based on the explanation above, it can be concluded that the application of the concept of Eco Tropical in the building of the Rehabilitation and Coastal Training Center was designed by taking into account several factors such as the orientation of the building, which is centered, the use of existing materials in the surrounding area, the view of the 
building prioritizing towards the beach as the main view, the building opening which is maximized so that air circulation is smooth, and building construction that can be used in the condition of the building area will be built. In addition to the aforementioned issues, it is also necessary to pay attention to a number of approaches such as the function approach as a means of accommodating activities, social approach so that the building can be accepted by the surrounding community, the climate approach pays attention to the condition of the climate where the building will be designed, and the location approach pays attention to where the location of the building will later be designed.

\section{REFERENCES}

[1] Akmal, Imelda, "Tropical Eco House", Jakarta Selatan : PT Imaji Media Pustaka, 2019.

[2] Darmasetiawan, Christian, Lestari Puspakesuma, "Teknik Pencahayaan dan Tata Letak Lampu Jilid 1 Pengetahuan Dasar", Jakarta: PT. Gramedia Widiasarana Indonesia, 1991. 